\title{
Polyunsaturated Fatty Acids of Blood Serum and the Assessment of their Ratios in Clinically Healthy Adults Living in the Arctic Territories of Russia
}

\author{
Fatima A. Bichkaeva, $\mathrm{PhD}, \mathrm{ScD}^{1 *}$; David S. Galstyan, $\mathrm{PGS}^{1}$; Natalia I. Volkova, $\mathrm{PhD}^{1}$; \\ Olga S. Vlasova, $\mathrm{PhD}^{1}$; Ekaterina V. Nesterova ${ }^{1}$; Artyom A. Bichkaev ${ }^{1}$; Boris A. Shengof ${ }^{1}$; \\ Andrey I. Popov, $\mathrm{PhD}^{2}$; Nina F. Baranova ${ }^{1}$ \\ ${ }^{1} N$. Laverov Federal Center for Integrated Arctic Research (FCIARctic) \\ ${ }^{2}$ Scientific Center for Arctic Research \\ Arkhangelsk, Russia
}

\begin{abstract}
Background: The study of the content of polyunsaturated fatty acids (PUFAs) in permanent residents of the Arctic territories, characterized by high activity of lipid metabolism, is of undoubted interest. The aim of this study was to assess the composition of omega-3 and omega-6 PUFAs in blood serum by gas-liquid chromatography and individual PUFA ratios in clinically healthy adults living in the Russian Arctic and Sub-Arctic regions.

Materials and Methods: A total of 1,556 healthy adult residents (the age groups of 22-35, 36-45 and 46-60 years) of the northern territories were examined. Of these, 661 people were living in the Sub-Arctic region (SAR) and 895 people in the Arctic region (AR). Analysis of PUFA composition in blood serum was determined by gas-liquid chromatography after transesterification to volatile fatty acid methyl esters (FAME). We determined the content of $\omega-3$ PUIFAs: $\alpha$-linolenic acid (ALA), eicosatrienoic acid (ETE), eicosapentaenoic acid (EPA), docosahexaenoic acid (DHA), docosapentaenoic acid (DPA); and $\omega-6$ PUFAs: dihomo- $\gamma$ linolenic acid (DGLA), linoleic acid (LA), arachidonic acid (AA), docosatetraenoic acid with the common name adrenic acid (AdA).

Results: In the clinically healthy individuals born and permanently living in SAR and AR, there was an age-related increase in LA level combined with an increase in the levels of AA, AdA and DGLA, as well as an increase in ALA level combined with an increase in the levels of EPA, DPA and DHA, the content of which was higher in AR individuals. In all age groups of adult residents of SAR, an increase in the AA/EPA ratio and a decrease in the EPA/DPA and (DGLA EPA)/DHA values were observed relative to similar age groups of AR, which indicates disorders in the PUFA metabolism and intensification of pro-inflammatory eicosanoid synthesis. In AR, a statistically significant increase in both $\omega-3$ and $\omega-6$ PUFAs can be a compensatory-adaptive reaction aimed at preserving the lipid component of cell membranes and reducing the risk of their destruction. An increase in the AA/DGLA ratio can be considered as a hidden risk criterion for the synthesis of pro-inflammatory eicosanoids.(International Journal of Biomedicine. 2019;9(4):338-344.)
\end{abstract}

Key Words: $\omega-3$ and $\omega-3$ polyunsaturated fatty acids $\bullet$ adults $\bullet$ Arctic and Sub-Arctic regions

\section{Introduction}

The lifestyle modification in recent years associated with the restriction of physical activity, an increase in the calorie content of food products and a steady increase in

*Corresponding author: Fatima A. Bichkaeva, PhD, ScD. N. Laverov Federal Center for Integrated Arctic Research FCIARctic of the RAS, Arkhangelsk, Russia.E-mail:fatima@fciarctic.ru emotional stress provokes adaptive changes in the content of serum lipids and in the redistribution of the composition of fatty acids in lipids of cell membranes. All this potentiates the main risk factors for dyslipidemia, diabetes and obesity. ${ }^{(1-3)}$

A chain of consecutive disorders, starting with the pathology of the fatty acid transporter protein, leads to a cell deficiency of essential fatty acids. Depletion of essential PUFAs in the cell membrane pool is a negative factor for the synthesis of oxylipins (eicosanoids)-bioactive lipid 
metabolites of PUFAs. ${ }^{(4-6)}$ It has been shown that an imbalance of oxylipins in the body causes chronic inflammation, arterial hypertension, coronary heart disease, atherosclerosis, and diabetes mellitus. ${ }^{(7-9)}$ Disturbances in the synthesis of eicosanoids lead to metabolic syndrome. At the same time, the transformation of the FA profile in membrane lipids not only changes the synthesis of oxylipins, but also causes a violation of their physicochemical properties with a decrease in fluidity, receptor sensitivity and membrane permeability. ${ }^{(10,11)}$ At the same time, the composition of essential blood serum PUFAs, reflecting the structural and functional changes in cells and the organism as a whole, significantly depends on the nature of nutrition. ${ }^{(12-14)}$

Although early studies have shown associations between PUFA imbalances and a number of diseases, ${ }^{(3,15,16)}$ there is insufficient information on the content of PUFAs in clinically healthy individuals living in the Arctic and Arctic regions. ${ }^{(17,18)}$ Polar human physiology merits intensified study because such a study would increase our knowledge of basic principles of biomedicine.

The aim of this study was to assess the composition of omega-3 and omega-6 PUFAs in blood serum by gas-liquid chromatography and individual PUFA ratios in clinically healthy adults living in the Russian Arctic and Sub-Arctic regions.

\section{Materials and Methods}

A total of 1,556 healthy (I and II health groups) adult residents (the age groups of 22-35, 36-45 and 46-60 years) of the northern territories were examined. Of these, 661 people (206 people in the age group of 22-35 years, 144 people in the age group of 36-45 years, and 311 people in the age group of 46-60 years old) were living in the Sub-Arctic region (SAR) (Primorsky, Konoshsky and Pinezhsky districts of the Arkhangelsk oblast) and 895 people (259 people - the age group of 22-35 years, 244 people in the age group of 36-45 years and 392 people in the age group of 46-60 years) in the Arctic region (AR) (Nenets and Yamalo-Nenets okrugs, Mezensky district of the Arkhangelsk oblast). As you know, the territories of AR are less comfortable for living than SAR due to climatic factors. In particular, AR is characterized by widespread permafrost, severe and prolonged winters with low temperatures, intense wind conditions and sharp changes in atmospheric pressure. Among the people surveyed in AR, $78 \%$ were indigenous northern peoples (Nenets, Komi, etc.) and $22 \%$ were the local Caucasoid population. Exclusion criteria were the presence of cardiovascular diseases and their complications, diabetes mellitus, thyroid diseases, acute pathological conditions and exacerbations of chronic diseases.

The study was conducted in accordance with ethical principles of the WMA Declaration of Helsinki (1964, ed. 2013) and approved by the FCIARctic Ethics Committee. Written informed consent was obtained from all participants.

Blood samples $(5 \mathrm{ml})$ were obtained from the ulnar vein on an empty stomach between 8:00 and 10.00 a.m. in IMPROVACUTER' Evacuated Blood Collection Tubes. The composition of PUFAs in the blood serum was determined by gas-liquid chromatography on an Agilent 7890A chromatographic system (Agilent Technologies, Santa Clara, California, USA) equipped with a flame ionization detector. SGE Analytical Science ${ }^{\mathrm{TM}}$ BPX90 GC Capillary Columns were used for fast separation of isomers of Fatty Acid Methyl Esters. ${ }^{(19)}$ We determined the content of $\omega-3$ PUIFAs: $\alpha$-linolenic acid (C18:3 n-3, ALA), eicosatrienoic acid (20:3 n-3, ETE), eicosapentaenoic acid (C20:5 n-3, EPA), docosahexaenoic acid (C22:6 n-3, DHA), docosapentaenoic acid (C22:5 n-3, DPA); and $\omega-6$ PUFAs: dihomo- $\gamma$-linolenic acid (C20:3 n-6, DGLA), linoleic acid (C18:2 n-6, LA), arachidonic acid (C20:4 n-6, AA), docosatetraenoic acid (C22:4 n-6), with the common name adrenic acid (AdA).

Chromatograms were integrated manually using ChemStation software (version B.03.01, Agilent Technologies). Fatty acid concentrations $(\mu \mathrm{g} / \mathrm{ml})$ were calculated by comparing the peak area of a fatty acid of interest with the internal standard (decanoic acid). The ratios of individual PUFAs were also calculated: AA/DHA, AA/EPA, AA/DGLA, AA/AdA, EPA/ DPA, DHA/DPA, LA/AdA, ETE+EPA/DHA.

Statistical analysis was performed using the statistical software SPSS version 22.0 (SPSS Inc, Chicago, IL). The normality of distribution of continuous variables was tested by one-sample Kolmogorov-Smirnov test. Variables were presented as median (Me) and interquartile ranges (IQR; 25 th to 75 th percentiles). Mann-Whitney $U$ test was used to compare means of 2 groups of variables not normally distributed. A probability value of $P<0.05$ was considered statistically significant.

\section{Results}

Comparison of the median values (Me) of LA, which is a substrate for the formation of other $\omega-6$ PUFAs, showed that in both regions its content increased with age. Moreover, the LA content in the age group of 46-60 years in SAR was significantly higher than in the same age group in AR. The marked age-related increase in the LA level was accompanied by a decrease in the proportion of people with an LA deficit (in SAR from 11.2 to $6.1 \%, P=0.038$; in AR from 12.0 to $4.8 \%, P=0.001$ ) and an increase in the proportion of people with an excess (in SAR from 10.2 to $22.2 \%, P<0.001$; in AR from $9.7 \%$ to $10.5 \%, P=0.42$ ).

The proportion of AA, the main substrate for the synthesis of pro-inflammatory eicosanoids, also increased with age in both regions. Moreover, in the age groups of 22$35,36-45$ and $46-60$ years in AR, its content was significantly higher compared with similar age groups in SAR. It should be noted that the AA level in the age group of 22-35 years in SAR was shifted toward lower normative levels (below the norm - $21.4 \%$ and above the norm $-9.7 \% ; P=0.22)$; in $\mathrm{AR}$, we noted equal percentages: below the norm $(15.5 \%)$ and above the norm (15.9\%). In the age groups of 36-45 and 46-60, there were fewer AA deficient conditions, and more excess AA values $(13.9 \%$ and $12.5 \% ; 16.2 \%$ and $19.5 \%$ in SAR; $9.1 \%$ and $25.1 \% ; 7.9 \%$ and 25.8 in AR). However, in all age groups in AR, compared with SAR, AdA levels were significantly higher, which, together with high AA levels, is an unfavorable factor in enhancing the synthesis of proinflammatory eicosanoids (Table 1). 
Table 1.

Levels of omega-3 and omega-6 PUFAs in blood serum in clinically healthy adults living in the Russian Arctic and Sub-Arctic regions

\begin{tabular}{|c|c|c|c|c|c|c|}
\hline \multirow{3}{*}{$\begin{array}{c}\text { PUFA (Norm) } \\
\mu \mathrm{g} / \mathrm{ml}\end{array}$} & & \multicolumn{3}{|c|}{ Age group } & \multicolumn{2}{|c|}{$P$-value } \\
\hline & \multirow{2}{*}{ Region } & $\begin{array}{l}\text { 22-35 years } \\
\text { (1) }\end{array}$ & $\begin{array}{c}\text { 36-45 years } \\
\text { (2) }\end{array}$ & $\begin{array}{l}\text { 46-60 years } \\
\text { (3) }\end{array}$ & \multirow{4}{*}{$\begin{array}{c}P \\
\text { (between the } \\
\text { age groups) }\end{array}$} & \multirow{4}{*}{$\begin{array}{c}P \\
\text { (between the } \\
\text { same age groups } \\
\text { for SAR and AR) }\end{array}$} \\
\hline & & $\operatorname{Me}(25 ; 75)$ & $\operatorname{Me}(25 ; 75)$ & $\operatorname{Me}(25 ; 75)$ & & \\
\hline \multirow{2}{*}{$\mathrm{n}$} & SAR & 206 & 144 & 311 & & \\
\hline & $\mathrm{AR}$ & 259 & 244 & 392 & & \\
\hline \multirow[t]{2}{*}{$\begin{array}{c}\text { LA (C18:2 n-6) } \\
371.97-1041.0\end{array}$} & SAR & $\begin{array}{c}642.57 \\
(453.5 ; 806.7)\end{array}$ & $\begin{array}{c}672.44 \\
(444.7 ; 936.8)\end{array}$ & $\begin{array}{c}766.21 \\
(555.1 ; 960.7)\end{array}$ & $\begin{array}{l}P_{1-2}=0.428 \\
P_{2-2}<0.001 \\
P_{2-3}=0.013\end{array}$ & \multirow{2}{*}{$\begin{array}{l}P_{1-1}=0.777 \\
P_{3-3}^{2-2}=0.577 \\
P_{3-3}=002\end{array}$} \\
\hline & $\mathrm{AR}$ & $\begin{array}{c}643.42 \\
(470.3 ; 824.4)\end{array}$ & $\begin{array}{c}692.98 \\
(521.9 ; 887.7)\end{array}$ & $\begin{array}{c}686.68 \\
(524.7 ; 858.4)\end{array}$ & $\begin{array}{l}P_{1-2}=0.031 \\
P_{2-3}^{1-3}=0.010 \\
P_{2-3}=0.976\end{array}$ & \\
\hline \multirow[t]{2}{*}{$\begin{array}{c}\text { AA (C20:4 n-6) } \\
26.33-139.53\end{array}$} & SAR & $\begin{array}{c}59.07 \\
(27.71 ; 104.01)\end{array}$ & $\begin{array}{c}62.93 \\
(35.44 ; 110.9)\end{array}$ & $\begin{array}{c}78.46 \\
(32.8 ; 123.6)\end{array}$ & $\begin{array}{l}P_{1-2}=0.241 \\
P_{1-3}=0.005 \\
P_{2-3}=0.182\end{array}$ & \multirow{2}{*}{$\begin{array}{l}P_{1-1}=0.002 \\
P_{2-2}^{2}<0.001 \\
P_{3-3}<0.001\end{array}$} \\
\hline & $\mathrm{AR}$ & $\begin{array}{c}81.56 \\
(41.5 ; 118.2)\end{array}$ & $\begin{array}{c}96.22 \\
(56.56 ; 139.5)\end{array}$ & $\begin{array}{c}91.26 \\
(58.95 ; 141.3)\end{array}$ & $\begin{array}{l}P_{1-2}=0.001 \\
P_{1-3}<0.001 \\
P_{2-3}=0.880\end{array}$ & \\
\hline \multirow{2}{*}{$\begin{array}{c}\text { AdA }(C 22: 4 \mathrm{n}-6) \\
1.09-6.15\end{array}$} & SAR & $\begin{array}{c}1.94 \\
(1.35 ; 2.95)\end{array}$ & $\begin{array}{c}1.32 \\
(1.02 ; 2.11)\end{array}$ & $\begin{array}{c}1.56 \\
(1.06 ; 2.27)\end{array}$ & $\begin{array}{l}P_{1-2}=0.066 \\
P_{2-3}^{1-3}=0.203 \\
P_{2-3}=0.461\end{array}$ & \multirow{2}{*}{$\begin{array}{l}P_{1-1}=0.012 \\
P_{2-2}<0.001 \\
P_{3-3}<0.001\end{array}$} \\
\hline & $\mathrm{AR}$ & $\begin{array}{c}3.15 \\
(1.77 ; 5.41)\end{array}$ & $\begin{array}{c}3.52 \\
(1.95 ; 5.01)\end{array}$ & $\begin{array}{c}3.19 \\
(2.08 ; 5.01)\end{array}$ & $\begin{array}{l}P_{1-2}=0.866 \\
P_{1-3}=0.947 \\
P_{2-3}=0.651\end{array}$ & \\
\hline \multirow{2}{*}{$\begin{array}{c}\text { ALA }(\mathrm{C} 18: 3 \mathrm{n}-3) \\
1.51-9.57\end{array}$} & SAR & $\begin{array}{c}3.54 \\
(1.86 ; 5.72) \\
\end{array}$ & $\begin{array}{c}4.258 \\
(2.50 ; 6.36) \\
\end{array}$ & $\begin{array}{c}4.68 \\
(3.08 ; 6.92) \\
\end{array}$ & $\begin{array}{l}P_{1-2}=0.011 \\
P_{1-3}<0.001 \\
P_{2-3}=0.084\end{array}$ & \multirow{2}{*}{$\begin{array}{l}P_{1-1}=0.000 \\
P_{3-3}^{2-2}<0.001 \\
P_{3-001}\end{array}$} \\
\hline & $\mathrm{AR}$ & $\begin{array}{c}4.64 \\
(2.98 ; 6.62)\end{array}$ & $\begin{array}{c}5.38 \\
(3.53 ; 7.17)\end{array}$ & $\begin{array}{c}5.80 \\
(4.056 ; 8.72)\end{array}$ & $\begin{array}{l}P_{1-2}=0.009 \\
P_{1-3}^{1-3}=0.001 \\
P_{2-3}=0.014\end{array}$ & \\
\hline \multirow{2}{*}{$\begin{array}{c}\mathrm{EPA}(\mathrm{C} 20: 5 \mathrm{n}-3) \\
3.36-71.38\end{array}$} & SAR & $\begin{array}{c}7.11 \\
(3.26 ; 12.31)\end{array}$ & $\begin{array}{c}8.91 \\
(3.97 ; 16.11)\end{array}$ & $\begin{array}{c}9.98 \\
(4.67 ; 19.39)\end{array}$ & $\begin{array}{l}P_{1-2}=0.019 \\
P_{1-3}<0.001 \\
P_{2-3}=0.224\end{array}$ & \multirow{2}{*}{$\begin{array}{l}P_{1-1}<0.001 \\
P_{2-2}^{2}<0.001 \\
P_{3-3}<0.001\end{array}$} \\
\hline & $\mathrm{AR}$ & $\begin{array}{c}13.80 \\
(6.48 ; 27.12)\end{array}$ & $\begin{array}{c}20.24 \\
(10.69 ; 38.42)\end{array}$ & $\begin{array}{c}23.07 \\
(10.4 ; 45.99)\end{array}$ & $\begin{array}{l}P_{1-2}<0.001 \\
P_{1-3}<0.001 \\
P_{2-3}=0.350\end{array}$ & \\
\hline \multirow{2}{*}{$\begin{array}{c}\text { DHA (C22:6 n-3) } \\
8.84-138.9\end{array}$} & SAR & $\begin{array}{c}20.56 \\
(9.39 ; 50.81)\end{array}$ & $\begin{array}{c}27.38 \\
(12.33 ; 59.93)\end{array}$ & $\begin{array}{c}37.01 \\
(12.49 ; 71.57)\end{array}$ & $\begin{array}{l}P_{1-2}=0.095 \\
P_{1-3}<0.001 \\
P_{2-3}=0.122\end{array}$ & \multirow{2}{*}{$\begin{array}{l}P_{1-1}=0.048 \\
P_{3-3}^{2-2}<0.0001\end{array}$} \\
\hline & $\mathrm{AR}$ & $\begin{array}{c}29.297 \\
(13.89 ; 53.05)\end{array}$ & $\begin{array}{c}44.23 \\
(22.10 ; 74.75)\end{array}$ & $\begin{array}{c}45.64 \\
(21.11 ; 85.08)\end{array}$ & $\begin{array}{l}P_{1-2}<0.001 \\
P_{1-3}<0.001 \\
P_{2-3}=0.247\end{array}$ & \\
\hline \multirow{2}{*}{$\begin{array}{c}\text { ETE }(20: 3 \mathrm{n}-3) \\
3.72-44.32\end{array}$} & SAR & $\begin{array}{c}15.04 \\
(6.01 ; 24.23) \\
\end{array}$ & $\begin{array}{c}15.74 \\
(7.92 ; 27.72)\end{array}$ & $\begin{array}{c}19.45 \\
(7.62 ; 32.11) \\
\end{array}$ & $\begin{array}{l}P_{1-2}=0.126 \\
P_{2-3}^{1-3}=0.001 \\
P_{2-166}\end{array}$ & \multirow{2}{*}{$\begin{array}{l}P_{1-1}=0.245 \\
P_{3-3}^{2-2}=0.075 \\
P_{3-258}\end{array}$} \\
\hline & $\mathrm{AR}$ & $\begin{array}{c}15.13 \\
(7.89 ; 25.79)\end{array}$ & $\begin{array}{c}19.314 \\
(10.61 ; 30.21)\end{array}$ & $\begin{array}{c}20.52 \\
(11.0 ; 31.1)\end{array}$ & $\begin{array}{l}P_{1-2}=0.009 \\
P_{1-3}<0.001 \\
P_{2-3}=0.409\end{array}$ & \\
\hline \multirow{2}{*}{$\begin{array}{c}\text { DPA }(C 22: 5 \mathrm{n}-3) \\
3.23-19.93\end{array}$} & SAR & $\begin{array}{c}4.03 \\
(2.11 ; 6.56)\end{array}$ & $\begin{array}{c}3.15 \\
(2.42 ; 5.78)\end{array}$ & $\begin{array}{c}3.34 \\
(2.31 ; 4.85)\end{array}$ & $\begin{array}{l}P_{1-2}=0.505 \\
P_{1-3}=0.407 \\
P_{2-3}=0.809\end{array}$ & \multirow{2}{*}{$\begin{array}{l}P_{1-1}<0.001 \\
P_{3-3}^{2-2}<0.001 \\
P_{3-001}\end{array}$} \\
\hline & $\mathrm{AR}$ & $\begin{array}{c}8.26 \\
(5.16 ; 13.46)\end{array}$ & $\begin{array}{c}8.64 \\
(5.05 ; 14.61)\end{array}$ & $\begin{array}{c}9.43 \\
(6.02 ; 13.37)\end{array}$ & $\begin{array}{l}P_{1-2}=0.522 \\
P_{1-3}=0.120 \\
P_{2-3}=0.563\end{array}$ & \\
\hline
\end{tabular}


In both regions, the content of EPA, the main antagonist of AA and AdA, was significantly higher in the age groups of 36-45 and 46-60 compared with the age group of 22-35 years. However, among the inhabitants of SAR, the EPA level in all age groups was significantly lower compared to similar age groups in AR. In addition, in SAR we found an age-related, statistically significant decrease in the percentage of people with EPA deficiency from $23.2 \%$ to $15.6 \%(P=0.031)$ (in AR from $11.2 \%$ to $9.5 \% ; P=0.83)$. In $\mathrm{AR}$, on the contrary, we noted a statistically significant increase in the percentage of people with EPA excess from $5.0 \%$ to $12.3 \%(P=0.002)$ (in SAR from $1.5 \%$ to $2.9 \% ; P=0.86)$. A decrease in the proportion of EPA in the blood was associated with a decrease in the proportion of DPA, especially in SAR.

With regard to DHA, a dynamics similar to EPA was found. Moreover, the level of DHA was significantly higher in AR compared to SAR. In both regions with age, we found a decrease in the percentage of people with DHA deficiency from $20.3 \%$ to $15.8 \%(P=0.062)$ in SAR and from $18.1 \%$ to $9.2 \%(P=0.001)$ in AR, and an increase in the percentage of people with DHA excess from $0.5 \%$ to $8.1 \%(P<0.001)$ in SAR and from $3.1 \%$ to $13.0 \%(P<0.001)$ in AR. That is, in SAR, the proportion of people with DHA deficiency was greater but the proportion with excess was less. Consequently, DHA deficiency in residents of both regions increases the likelihood of synthesis of pro-inflammatory eicosanoids, especially in SAR.

The content of the essential ALA, which is the precursor of EPA and DHA, was significantly increased in the age groups of 36-45 and 46-60 in both regions relative to the age group of 22-35 years. Moreover, in the age group of 22-35 years, the limits of its fluctuations were multidirectional. In SAR, they were shifted mainly toward lower than normative values (below the norm - 17.5\% and above the norm - 6.6\%, $P<0.001$ ), and in AR, on the contrary, higher than normative values (above the norm $-7.3 \%$ and above the norm $-14.3 \%$, $P=0.017$ ). In the age groups of $36-45$ and $46-60$, in both regions, ALA content was shifted only toward higher than normative values, but the proportion of people with an excess of it in SAR was less than in AR (10.40\% and $15.80 \%$ versus $14,80 \%$ and $26.40 \% ; P=0.216$ and $P<0.001)$.

Thus, in the clinically healthy individuals born and permanently living in SAR and AR, there was an age-related increase in LA level combined with an increase in the levels of AA, AdA and DGLA, as well as an increase in ALA level combined with an increase in the levels of EPA, DPA and DHA, the content of which was higher in AR individuals.

Thus, in clinically healthy residents of SAR and AR, we revealed a statistically significant, age-related increase in the level of $\omega-3$ and $\omega-6$ PUFAs, which may be a compensatoryadaptive reaction of the body to constantly acting the extreme factors of the North. At the same time, a statistically significant increase in the level of AA and AdA among residents of AR of all age groups, relative to similar age groups of SAR, occurred against the background of a statistically significant increase in the main inhibitors and competitors for cyclooxygenase and lipoxygenase metabolic pathways of EPA and DHA. All of the above, in our opinion, may indicate an increase in the synthesis of anti-inflammatory eicosanoids and an improvement in the fluidity of the phospholipid liquid crystal structure of cell membranes, and may indirectly indicate a slight decrease in the risk of developing metabolically caused diseases in people of AR. One of the reasons for the age-related changes in the content of PUFAs found in the blood of northerners (especially in SAR) that we have identified may be both disorders in PUFA active transport and an unbalanced diet, in particular, the consumption of easily digestible carbohydrates and trans fats. ${ }^{(12,14)}$ Since PUFAs are the main substrate of lipid peroxidation, their low content in the blood of residents of SAR indicates an increase in oxidative processes and the formation of atherogenic lipid fractions. ${ }^{(20,21)}$ At the same time, the revealed changes in the level of AA, namely in residents of AR, were combined with a higher frequency of occurrence of excess states of LA. This, in our opinion, happens because the set of climatic factors of the North stimulates the release of stress hormones and enhances lipolysis. In addition, an increase in the level of AA and its age-related excess in residents of AR occurred with a significant deficiency of its main inhibitor and competitor for cyclooxygenase and lipoxygenase metabolic pathways, EPA, the level of which also increased, but the deficit remained high. This, in our opinion, can lead to a change in the physicochemical properties of plasma membranes and activation of the synthesis of eicosanoids with pro-inflammatory activity.

During the analysis, we also studied the ratio of PUFAs, taking into account the age and region of residence (Table 2). Traditionally, the availability of PUFAs comes down to their qualitative and quantitative determination, analysis of the ratios of $\omega-3$ and $\omega-6$ acids between themselves and their total content $\left(\sum \omega-6 / \sum \omega-3\right)$. However, the results of studies in recent years indicate that these coefficients do not always correctly reflect the functional properties of $\omega-3$ and $\omega-6$ PUFAs. ${ }^{(22-25)}$ Considering that one of the real reasons for the transformation of PUFA composition is the change in their role in metabolism, we analyzed some indicators of this process: the AA/ETE ratio indirectly reflects the activity of D5-desaturase; the DHA/ DPA ratio shows the activity of enzymes in the last stage of FA biosynthesis; the AA/AdA ratio and EPA/DPA ratio are indicators of the activity of FA elongases. In addition, the ratios of AA/DHA and (ETE+EPA)/DHA reflected the metabolic state in the eicosanoid cycle, and the AA/EPA ratio allowed us to assess the level of cellular inflammation. The informative significance of the presented criteria has been proved for patients with cardiovascular pathology, ${ }^{(1,3)}$ but there are no data on clinically healthy individuals.

The analysis of the values we obtained did not reveal significant changes in the value of AA/DGLA in people of both regions with increasing age, but when comparing similar age groups, the value of this ratio in people of AR was significantly higher compared to SAR. This indirectly indicates an increase in the activity of D5-desaturase catalyzing the reaction of substrate synthesis for eicosanoids of the second and fourth series. At the same time, in both regions, we found an age-related decrease in the AA/EPA ratio and an increase in the AA/AdA ratio, which characterize the relationship between the precursor of eicosanoid synthesis and the inhibitor of their formation. A comparison of 
similar age groups of SAR and AR showed that the inhabitants of SAR, on the one hand, had a significantly higher AA/ EPA ratio, but on the other hand, the values of EPA/DPA and
(DGLA+EPA)/DHA were significantly lower, which indicates disorders in the metabolism of PUFAs and intensification of proinflammatory eicosanoid synthesis (Table 2).

Table 2.

The ratio of PUFAs in blood serum in clinically healthy adults living in the Russian Arctic and Sub-Arctic regions

\begin{tabular}{|c|c|c|c|c|c|c|}
\hline \multirow{3}{*}{$\begin{array}{c}\text { The ratio of PUFAs, } \\
\text { conv. units }\end{array}$} & \multirow{3}{*}{ Region } & \multicolumn{3}{|c|}{ Age group } & \multicolumn{2}{|c|}{$P$-value } \\
\hline & & $\begin{array}{l}\text { 22-35 years } \\
\text { (1) }\end{array}$ & $\begin{array}{c}36-45 \text { years } \\
(2)\end{array}$ & $\begin{array}{c}\text { 46-60 years } \\
\text { (3) }\end{array}$ & \multirow{4}{*}{$\begin{array}{c}P \\
\text { (between the } \\
\text { age groups) }\end{array}$} & \multirow{4}{*}{$\begin{array}{c}P \\
\text { (between the } \\
\text { same age groups } \\
\text { for SAR and AR) }\end{array}$} \\
\hline & & $\operatorname{Me}(25 ; 75)$ & $\operatorname{Me}(25 ; 75)$ & $\operatorname{Me}(25 ; 75)$ & & \\
\hline \multirow{2}{*}{$\mathrm{n}$} & SAR & 206 & 144 & 311 & & \\
\hline & AR & 259 & 244 & 392 & & \\
\hline \multirow[t]{2}{*}{ AA/DHA } & SAR & $\begin{array}{c}2.55 \\
(1.78 ; 3.86) \\
\end{array}$ & $\begin{array}{c}2.27 \\
(1.58 ; 3.54) \\
\end{array}$ & $\begin{array}{c}2.19 \\
(1.52 ; 3.24) \\
\end{array}$ & $\begin{array}{l}P_{1-2}=0.068 \\
P_{1-3}=0.001 \\
P_{2-3}=0.286\end{array}$ & \multirow{2}{*}{$\begin{array}{l}P_{1-1}=0.623 \\
P_{2-2}=0.519 \\
P_{3-3}=0.050\end{array}$} \\
\hline & $\mathrm{AR}$ & $\begin{array}{c}2.63 \\
(1.90 ; 3.79) \\
\end{array}$ & $\begin{array}{c}2.30 \\
(1.67 ; 3.0) \\
\end{array}$ & $\begin{array}{c}2.06 \\
(1.38 ; 2.96) \\
\end{array}$ & $\begin{array}{l}P_{1-2}<0.001 \\
P_{1-3}<0.001 \\
P_{2-3}=0.014\end{array}$ & \\
\hline \multirow[t]{2}{*}{ AA/EPA } & SAR & $\begin{array}{c}8.97 \\
(4.79 ; 15.40) \\
\end{array}$ & $\begin{array}{c}6.43 \\
(3.8 ; 13.27) \\
\end{array}$ & $\begin{array}{c}6.80 \\
(3.9 ; 13.06) \\
\end{array}$ & $\begin{array}{l}P_{1-2}=0.896 \\
P_{1-3}=0.006 \\
P_{2-3}=0.985\end{array}$ & \multirow{2}{*}{$\begin{array}{l}P_{1-1}<0.001 \\
P_{2-2}<0.001 \\
P_{3-3}<0.001\end{array}$} \\
\hline & $\mathrm{AR}$ & $\begin{array}{c}5.45 \\
(2.81 ; 9.33) \\
\end{array}$ & $\begin{array}{c}4.05 \\
(2.36 ; 7.59) \\
\end{array}$ & $\begin{array}{c}3.85 \\
(2.25 ; 7.85) \\
\end{array}$ & $\begin{array}{l}P_{1-2}=0.013 \\
P_{1-3}=0.001 \\
P_{2-3}=0.484\end{array}$ & \\
\hline \multirow[t]{2}{*}{ AA/DGLA } & SAR & $\begin{array}{c}4.34 \\
(3.35 ; 5.93) \\
\end{array}$ & $\begin{array}{c}4.28 \\
(3.14 ; 5.89) \\
\end{array}$ & $\begin{array}{c}4.22 \\
(3.24 ; 5.66)\end{array}$ & $\begin{array}{l}P_{1-2}=0.280 \\
P_{1-2}=0.198 \\
P_{2-3}=0.981\end{array}$ & \multirow{2}{*}{$\begin{array}{l}P_{1-1}=0.014 \\
P_{2-2}=0.001 \\
P_{3-3}=0.009\end{array}$} \\
\hline & $\mathrm{AR}$ & $\begin{array}{c}4.81 \\
(3.52 ; 7.71)\end{array}$ & $\begin{array}{c}5.10 \\
(3.69 ; 6.98)\end{array}$ & $\begin{array}{c}4.52 \\
(3.36 ; 6.69)\end{array}$ & $\begin{array}{l}P_{1-2}=0.925 \\
\mathrm{P}_{1-3}=0.100 \\
\mathrm{P}_{2-3}=0.073\end{array}$ & \\
\hline \multirow[t]{2}{*}{ DHA/DPA } & SAR & $\begin{array}{c}4.82 \\
(3.86 ; 7.08)\end{array}$ & $\begin{array}{c}4.15 \\
(3.0 ; 4.99) \\
\end{array}$ & $\begin{array}{c}4.61 \\
(3.82 ; 5.23)\end{array}$ & $\begin{array}{l}P_{1-2}=0.050 \\
P_{1-2}=0.235 \\
P_{2-3}=0.270\end{array}$ & \multirow{2}{*}{$\begin{array}{l}P_{1-1}=0.404 \\
P_{2-2}=0.042 \\
P_{3-3}=0.178\end{array}$} \\
\hline & $\mathrm{AR}$ & $\begin{array}{c}4.60 \\
(3.58 ; 6.01) \\
\end{array}$ & $\begin{array}{c}4.78 \\
(3.53 ; 6.33) \\
\end{array}$ & $\begin{array}{c}4.88 \\
(3.66 ; 6.54) \\
\end{array}$ & $\begin{array}{l}P_{1-2}=0.468 \\
P_{1-3}=0.223 \\
P_{2-3}=0.697\end{array}$ & \\
\hline \multirow[t]{2}{*}{$\mathrm{AA} / \mathrm{AdA}$} & SAR & $\begin{array}{c}24.19 \\
(20.68 ; 33.53) \\
\end{array}$ & $\begin{array}{c}27.83 \\
(23.14 ; 33.72) \\
\end{array}$ & $\begin{array}{c}23.33 \\
(18.62 ; 30.38) \\
\end{array}$ & $\begin{array}{l}P_{1-2}=0.352 \\
P_{1-3}=0.354 \\
P_{2-3}=0.044\end{array}$ & \multirow{2}{*}{$\begin{array}{l}P_{1-1}=0.408 \\
P_{2-2}=0.259 \\
P_{3-3}<0.001\end{array}$} \\
\hline & AR & $\begin{array}{c}26.19 \\
(20.30 ; 41.31) \\
\end{array}$ & $\begin{array}{c}28.88 \\
(23.07 ; 43.0) \\
\end{array}$ & $\begin{array}{c}29.63 \\
(22.64 ; 46.28) \\
\end{array}$ & $\begin{array}{l}P_{1-2}=0.085 \\
P_{1-3}=0.020 \\
P_{2-3}=0.511\end{array}$ & \\
\hline \multirow[t]{2}{*}{ EPA/DPA } & SAR & $\begin{array}{c}1.997 \\
(1.56 ; 2.45)\end{array}$ & $\begin{array}{c}1.97 \\
(1.24 ; 2.68) \\
\end{array}$ & $\begin{array}{c}1.89 \\
(1.19 ; 2.41) \\
\end{array}$ & $\begin{array}{l}P_{1-2}=0.747 \\
P_{1-3}=0.500 \\
P_{2-3}=0.726\end{array}$ & \multirow{2}{*}{$\begin{array}{l}P_{1-1}=0.05 \\
P_{2-3}^{2-2}<0.011 \\
P_{3-3}<0.001\end{array}$} \\
\hline & $\mathrm{AR}$ & $\begin{array}{c}2.38 \\
(1.39 ; 3.93) \\
\end{array}$ & $\begin{array}{c}2.698 \\
(1.60 ; 4.68) \\
\end{array}$ & $\begin{array}{c}2.84 \\
(1.65 ; 4.22) \\
\end{array}$ & $\begin{array}{l}P_{1-2}=0.104 \\
P_{1-3}=0.031 \\
P_{2-3}=0.761\end{array}$ & \\
\hline \multirow[b]{2}{*}{ DGLA+EPA/DHA } & SAR & $\begin{array}{c}0.92 \\
(0.68 ; 1.43)\end{array}$ & $\begin{array}{c}0.94 \\
(0.65 ; 1.51)\end{array}$ & $\begin{array}{c}0.832 \\
(0.65 ; 1.27)\end{array}$ & $\begin{array}{l}P_{1-2}=0.760 \\
P_{1-3}=0.328 \\
P_{2-3}=0.250\end{array}$ & \multirow{2}{*}{$\begin{array}{l}P_{1-1}<0.001 \\
P_{2-2}=0.134 \\
P_{3-3}=0.005\end{array}$} \\
\hline & AR & $\begin{array}{c}1.121 \\
(0.87 ; 1.61)\end{array}$ & $\begin{array}{c}1.03 \\
(0.78 ; 1.43)\end{array}$ & $\begin{array}{c}0.96 \\
(0.73 ; 1.33)\end{array}$ & $\begin{array}{l}P_{1-2}=0.021 \\
P_{1-3}<0.001 \\
P_{2-3}=0.150\end{array}$ & \\
\hline
\end{tabular}


Thus, in clinically healthy northerners, especially those living in SAR, pronounced changes were found in PUFA metabolism and eicosanoid biosynthesis due to inhibition of the activity of enzymes in the initial and last stages of the essential PUFA metabolism with reciprocal inhibition of synthesis of the cyclooxygenase and lipoxygenase metabolites of $\omega-3$ PUFAs. Obviously, an increase in the AA/EPA ratio in residents of SAR and in the AA/DGLA ratio in residents of AR may be a significant factor in the increased risk for the development of metabolic syndrome in the examined adults.

The results obtained indicate a transformation of the PUFA composition in the blood serum of clinically healthy adults, due to a change in their metabolism, competitive inhibition of the biosynthesis of $\omega-3$ PUFAs, and the marked increase in the formation of $\omega-6$ PUFAs and proinflammatory eicosanoids. It can be concluded that residents of the Arctic, especially living in SAR, starting from 22-35 years old, develop changes in lipid metabolism at the cellular level.

\section{Conclusions}

In all age groups of adult residents of the Sub-Arctic region, an increase in the AA/EPA ratio and a decrease in the EPA/DPA and (DGLA+EPA)/DHA values were observed relative to similar age groups of the Arctic region, which indicates disorders in the PUFA metabolism and intensification of pro-inflammatory eicosanoid synthesis.

In the Arctic region, a statistically significant increase in both $\omega-3$ and $\omega-6$ PUFAs can be a compensatory-adaptive reaction aimed at preserving the lipid component of cell membranes and reducing the risk of their destruction. An increase in the AA/DGLA ratio can be considered as a hidden risk criterion for the synthesis of pro-inflammatory eicosanoids.

\section{Competing Interests} interests.

The authors declare that they have no competing

\section{Sources of Funding}

The reported study was funded by the FCIARctic according to the research project: "The study of adaptive age-related endocrine and metabolic rearrangements in residents of the Arctic territories" (State registration number AAAA-A15-115122810187-7).

\section{References}

1. Psota TL, Gebauer SK, Kris-Etherton P. Dietary omega-3 fatty acid intake and cardiovascular risk. Am J Cardiol. 2006;98(4A):3i-18i.

2. Zhou YE, Kubow S, Dewailly E, Julien P. Decreased activity of desaturase 5 in association with obesity and insulin resistance aggravates declining long-chain n-3 fatty acid status in Cree undergoing dietary transition. Br J Nutr 2009;102(6):888-94. doi: 10.1017/S0007114509301609.

3. Drapkina OM, Shepel' RN. [Omega-3 fatty acids and age-related diseases: realities and prospects]. Rational Pharmacotherapy in Cardiology 2015;11(3):309-316. [Article in Russian].

4. Stillwell W, Wassall SR. Docosahexaenoic acid: membrane properties of a unique fatty acid. Chem Phys Lipids. 2003;126(1):1-27.

5. Novgorodtseva TP, Karaman YK, Zhukova NV, Lobanova EG, Antonyuk MV, Kantur TA. Composition of fatty acids in plasma and erythrocytes and eicosanoids level in patients with metabolic syndrome. Lipids in Health and Disease. 2011; 10(82):82-86. doi: 10.1186/1476-511X-10-82.

6. Nazarov PE, Myagkova GI, Grosa NV. [Polyunsaturated fatty acids as universal endogenous bioregulators]. Fine Chemical Technologies. (Vestnik. MITHT). 2009;4(5):3-19. [Article in Russian].

7. Calder PC. n-3 polyunsaturated fatty acids, inflammation, and inflammatory diseases. Am J Clin Nutr. 2006;83(6 Suppl):1505S-1519S. doi: 10.1093/ajen/83.6.1505S.

8. Lorente-Cebrián S, Costa AG, Navas-Carretero $\mathrm{S}$, Zabala M, Laiglesia LM, Martínez JA, Moreno-Aliaga MJ. An update on the role of omega-3 fatty acids on inflammatory and degenerative diseases. J Physiol Biochem. 2015;71(2):341-9. doi: 10.1007/s13105-015-0395-y.

9. Novgorodtseva YP, Denisenko YuK, Antonyuk MV, Zhukova NV. [Modification of fatty acid content of cell membranes of erythrocytes at chronic obstructive pulmonary disease]. Bulletin SB RAMS. 2013;33(5):64-69.[Article in Russian].

10. Taratukhin EO. [Atherosclerosis and fatty acids: important association and new therapeutic approach]. Russian Journal of Cardiology. 2011;(5):77-80. [Article in Russian].

11. Williams JA, Batten SE, Harris M, Rockett BD, Shaikh SR, William S, Wassall SR. Docosahexaenoic and eicosapentaenoic acids segregate differently between raft and nonraft domains. Biophys J. 2012;103(2):228-37. doi: 10.1016/j.bpj.2012.06.016.

12. Chanchaeva EA. [On the issue of adequate nutrition of the indigenous population of Siberia]. Human Ecology. 2010;3: 31-34. [Article in Russian].

13. Innis SM. Omega-3 fatty acid biochemistry: perspectives from human nutrition. Mil Med. 2014;179(11 Suppl):82-7. doi: 10.7205/MILMED-D-14-00147.

14. Lobanov AA, Bogdanova EN, Andronov SV, Popov AI, Kochkin RA, Kostricin VV, et al. [A study of the traditional diet of residents of the Arctic zone of Western Siberia]. Problems of Nutrition. 2018; 87(5):31-32. doi: 10.24411/0042-88332018-10114. [Article in Russian].

15. Novgorodtseva TP, Denisenko YK, Antonyuk MV, Yubitskaya NS, Lobanova EG, Zhukova NV. [Blood fatty acids in the development and correction of metabolic syndrome]. Ter Arkh. 2016;88(8):30-34. doi: 10.17116/terarkh201688830-34. [Article in Russian].

16. Denisenko YuK, Vitkina TI, Kondratyeva EV, Zhukova NV, Nazarenko AV. [Modification of the composition of fatty acids in membranes of mitochondria of platelets in patients with chronic non-obstructive bronchitis]. Health, Medical ecology, Science. 2014;2(56):59-61. [Article in Russian]. 17. Bichkaev AA, Bichkaeva FA, Volkova NI, Tret'yakova TV, Vlasova OS, Nesterova EV, et al. [The Ratio of Blood Levels of Saturated Fatty Acids and Metabolites of 
Carbohydrate Metabolism in Residents of the Arctic Aged 22-35 Years]. Journal of Medical and Biological Research. 2017;5(2):44-55. doi: 10.17238/issn2542-1298.2017.5.2.44. [Article in Russian].

18. Bichkaeva FA. Endocrine regulation of metabolic processes in humans in the North. Ekaterinburg UrB RAS; 2008:303. [In Russian].

19. Bichkaeva FA. Baranova NF, Vlasova OS, Tret'yakova TV, Nesterova EV, Shengof BA, et al. A method for measuring the mass concentration of fatty acid methyl esters (FAMEs) in blood serum by gas-liquid chromatography. Register of measurement procedures UrB RAS. № 88-16365-001-2019. № SR.1.31.2019.33742. [In Russian].

20. Denisenko YuK, Novgorodtseva TP, Zhukova NV, Lobanova NG, Antonyuk MV. [Metabolic transformations of polyunsaturated fatty acids in chronic inflammatory diseases of the respiratory system]. Mezdunarodnii zhurnal prikladnih i fundamental'nih issledovanii. 2015;11(2):201-206. [Article in Russian].

21. Vasilkova TN, Mataev SI. [Metabolic a syndrome in population of the radical people of the extreme North]. Bulletin of the South Ural State University. Series: Education, Health, Physical Culture. 2009;27(160):71-73. [Article in Russian]. 22. Huang CW, Chien YS, Chen YJ, Ajuwon KM, Mersmann HM, Ding ST. Role of n-3 Polyunsaturated Fatty Acids in Ameliorating the Obesity-Induced Metabolic Syndrome in Animal Models and Humans. Int J Mol Sci. 2016;17(10). pii: E1689.

23. Maki KC, Eren F, Cassens ME, Dicklin MR, Davidson MH. $\omega-6$ Polyunsaturated Fatty Acids and Cardiometabolic Health: Current Evidence, Controversies, and Research Gaps. Adv Nutr. 2018;9(6):688-700. doi: 10.1093/advances/ nmy038.

24. Kromhout D, de Goede J. Update on cardiometabolic health effects of omega-3 fatty acids. Curr Opin Lipidol 2014;25:85-90.

25. Berger ME, Smesny S, Kim SW, Davey CG, Rice S, Sarnyai Z, Schlögelhofer M. et al. Omega-6 to omega-3 polyunsaturated fatty acid ratio and subsequent mood disorders in young people with at-risk mental states: a 7-year longitudinal study. Transl Psychiatry. 2017;7(8):e1220. doi: 10.1038/tp.2017.190. 